\title{
The socio-parasite and bio-parasite metaphorical concepts in racist discourse
}

\begin{abstract}
Defined as the transfer of meaning from one conceptual domain to another (Lakoff and Johnson 1980; Lakoff 1993), metaphors play a key role not only in the thought process, where they facilitate the understanding of complex concepts, as well as determine and shape people's attitudes and perceptions of reality, but also in the way we speak, as they strongly influence the storage and organisation of information. The main aim of the paper is to identify and evaluate the PEOPLE ARE PARASITES metaphor employed while referring to racial outgroups, and to review its different forms of usage on the white-supremacist Internet forum Stormfront.org according to the BIO-PARASITE / SOCIO-PARASITE categorisation framework proposed by Musolff (2016). The analysis of the metaphors unveils a slight target-dependant variation in the conceptual frame employed, which, in consequence, may influence the actions of forum users.
\end{abstract}

Key words: Conceptual Metaphor Theory, socio-parasite, bio-parasite, racism, antisemitism, ideology.

\section{BIO-PARASITE and SOCIO-PARASITE as metaphorical concepts}

Since the publication of Lakoff and Johnson's influential book Metaphors We Live By in 1980 Conceptual Metaphor Theory (CMT) has inspired extensive research into the influence of our language system on our perception of reality and resulting actions. The CMT view of a metaphor extends beyond its usage as a decorative rhetorical device: metaphors allow us to understand and express complex, abstract or problematic concepts through others that are "highly structured and clearly delineated" (Lakoff and Johnson 1980: 61) in the process that Lakoff and Johnson call metaphorical mapping (ibid. 246) or cross-domain mapping (Lakoff 1993: 203) between the source domain and the actual target (ibid. 207). As our experience of reality is largely structured by a conceptual system that is predominantly metaphorical in nature (see Lakoff and Johnson 1980/2003: 3f), metaphors also shape how we perceive ourselves and the surrounding reality, and can therefore determine our actions and reactions to various phenomena. ${ }^{1}$ Considering that one's conceptual system is generally not consciously acknowledged, our behaviour is mostly automatic (ibid. 3), and that is

1 For a study of behavioural responses to different metaphorical framings of the social issue of crime see Thibodeau et al. 2009. 
why consistently repeated and reinforced metaphors have the potential to modify our worldview, and consequently our actions, without our awareness. This feature makes the metaphor a dangerous weapon in the arsenal of political propaganda. As shown by many examples in history, this weapon can be especially deadly when employed in the context of the 'us' against 'them' antithesis, such as the representation of racial and ethnic minorities.

Parasites are one of the most prevalent source domains of metaphors in racist and extreme rightwing political discourse, but the concept is by no means uniform. For the purpose of this paper I will employ the BIO-PARASITE/SOCIO-PARASITE categorisation framework proposed by Musolff (2016). The general PEOPLE ARE PARASITES metaphor is aimed not only at degrading, demeaning, and dehumanising an individual or group; it also serves as an argument justifying banishment and, in extreme cases, total annihilation of whoever happens to be the target. The categorisation of an outgroup as parasites is a prototypical example of semantic mapping between the source domain of biology and the social target domain, where the parasite is presented as a menace for two reasons: first, it feeds off the life force of the host, and second, it simultaneously infects the body with a DEADLY DISEASE (see Musolff 2016: 73). The metaphor implies the urgent need to get rid of the parasite in order to save the host body, which makes it the weapon of choice in propaganda discourse advocating the total extermination of the enemy. It is important to note that parasites themselves do not actually elicit a fear response similar to that we experience when attacked by a wild animal; it is rather the feeling of disgust and the threat of infection and contamination that incites the urge to get rid of the foreign body. This universal human reaction to all things loathsome and repulsive is known as the behavioural immune system. This series of self-defensive psychological mechanisms is aimed at protecting the body against the threat of infection by (1) detecting the presence of pathogens that could potentially enter the body, (2) eliciting an aversive emotional and cognitive response, and (3) promoting a behavioural reaction to the threat (see Schaller and Park 2011). The feeling of disgust plays a key role in the behavioural immune system, and is thus crucial for ensuring survival and maintaining health when the risk of an actual biological infection is high (ibid. 100). However, a similar reaction can be observed when no real risk of contagion is present - the response is instead triggered by an association of an outgroup with issues of disease and infection, for instance a comparison to a viable biological threat such as a parasite. Hodson et al. argue:

(1) To the extent that an outgroup reminds us of something disgusting, or is associated with contagionrelevant concerns, the outgroup can itself evoke a disgust reaction. In addition, the practices and norms of another group can instantiate an automatic disgust reaction even when that group does not directly pose a sense of threat to one's own group (Hodson et al. 2014: 274).

The most infamous usage of the PEOPLE ARE PARASITEs metaphor is undoubtedly Third Reich propaganda, where it was used to legitimise the Holocaust during World War II. Jews were represented as parasitic organisms such as leeches, lice, bacteria or viruses (see Smith 2011: 26). Their 
extermination was thus seen as a therapeutic activity and a matter of hygiene. The worldview presented in Nazi propaganda is perhaps best summarised by the German scholar Musolff in his analysis of figurative language in Mein Kampf, Adolf Hitler's 1925 autobiographical book:

(2) The source imagery of Hitler's political worldview consisted in the conceptualization of the German (but, in principle, every) nation as a human body that had to be shielded from disease (or, in case of an outbreak, cured). Jewish people, who were conceptually condensed into the super-category of "the Jew" and viewed as an illness-spreading parasite, represented the danger of disease. Deliverance from this threat to the nation's life would come from Hitler and his party as the only competent healers who were willing to fight the illness (Musolff 2007: 25).

The Holocaust, although undoubtedly the most well-known, is certainly not the only instance of using the PEOPLE ARE PARASITES metaphor throughout history. Just like the Jews in the Third Reich, Armenians were likened to parasites in Turkish propaganda during the genocide of 19151953, with an equally gruesome outcome: an estimated 1.5 million people were murdered by starvation, stabbing, clubbing or other methods that did not require the use of bullets, which were deemed too valuable (Smith 2011: 156). Similarly, the metaphor was used during the Chinese Cultural Revolution in 1966 to label capitalist 'enemies of the state' that the Party needed to be rid of (ibid. 149); approximately 1.5 million people were killed, and millions of others suffered imprisonment and torture. These are just some examples that illustrate the implications of such a conceptualisation of the enemy; still, it is plain to see that the PEOPLE ARE PARASITES metaphor can be directly linked to genocide, and "those who use parasite metaphors to stigmatise others risk being accused of articulating a Nazi-like world view" (Musolff 2016: 73).

Due to its widespread usage, the term parasite is certainly worth a closer inspection. Musolff (2016: 74) distinguishes two main variations of the term parasite: bio-parasite - a plant, fungus or animal that feeds off another organism and transmits a potentially lethal disease, and socio-parasite, an individual or a group that lives at the expense of others. The dictionary definition reveals that parasite, derived from the ancient Greek parasitos ("person who eats at the table of another", Online Etymology Dictionary), was originally used to denote a priest who participated in communal meals, and later employed to humorously describe any freeloader that takes from a community without offering anything substantial in return (see Musolff 2016: 75). As the term became a biological category only in the mid-seventeenth century and had not been lexicalised as such before the eighteenth century, it is surprising to note that the concept of socIO-PARASITE actually predates that of BIO-PARASITE, with the transfer of meaning from the social to the biological domain (according to CMT, it is rather expected that a concrete concept would be used to facilitate understanding of an abstract one) (ibid. 75f).

With its widespread use in biological research at the end of the eighteenth century, the term parasite was once more re-metaphorised from the biological to the social domain, but this time it was applied to whole groups instead of isolated individuals, and its usage lost all its comedic un- 
dertones due the comparison to potentially dangerous parasitic plant and animal species (see $\mathrm{Mu}$ solff 2016: 77). Because of that, the referents were no longer categorised as humans, but rather as a separate species of organisms that feeds of the BODY of a nation. It is in that form that the socIOPARASITE concept came into usage in dehumanising discourse as a metaphor targeting the monarchy, aristocracy, bourgeoisie, capitalists, etc. in revolutionary wars from the eighteenth to the twentieth century (ibid. 76). The Soviet Union introduced actual anti-parasite legislation in 1961, allowing courts to sentence individuals who either refused to work or whose labour was considered an insufficient contribution to society (including intellectuals and artists, as well as political dissidents) to up to five years of exile (see Fitzpatrick 2006). The concept that Musolff refers to as SOCIO-PARASITE 2 "became a class name for groups that were deemed to damage the whole society and needed to be controlled or destroyed" (2016: 77), meaning that, for the first time in history, the term parasite was linked to dehumanisation, violence towards whole outgroups, and mass killings. This new concept of socio-parasite is perhaps best illustrated by the narrator in the 1940 Nazi propaganda film Der Ewige Jude: "He buys and sells, but produces nothing. The production he leaves to the workers and farmers of the host nation. The Jews are a people without farmers or workers: a race of parasites" (Hippler 1940, English subtitles provided on the website). The Jews are presented in the film as a collective that unscrupulously employs an immoral and destructive economic strategy in order to exploit the HOST nation. What makes them especially dangerous is the fact that it is not enough for them to simply use the resources without making any contribution to society; it is in their best interest to deteriorate the condition of the HOST BODY by infecting it with a deadly disease. The narrator continues: "Wherever the body of a nation shows a wound, they anchor themselves and feed on the decaying organism. They make business out of the sickness of a nation, and therefore endeavour to deepen and prolong all conditions of sickness" (Hippler 1940). The Jews are thus a parasite of a dual kind: not only a SOCIO-PARASITE, but also a re-metaphorised version of a BIO-PARASITE - an organism that infects the body and causes a physical illness. This new concept, which Musolff calls BIO-PARAsite 2, is the result of yet another change of direction in the transfer of meaning, this time from the social to the biological domain (Musolff 2016: 77f). The prevalence of the SOcIO-PARASITE concept in public discourse led to the anthropomorphisation of parasites in scientific research, implying that these organisms are in fact "intentionally and deliberately 'insidious', 'harmful' or 'destructive"' (Musolff 2016: 78). Anthropomorphism in source domains of animalistic metaphors is generally a common phenomenon, with animals such as wolves, pigs and rats often being accused of possessing the same worst character traits we fear in humans. As Waytz et al. point out:

(3) Anthropomorphism goes beyond providing purely behavioral or dispositional descriptions of observable actions (such as noting that a coyote is fast or aggressive); it involves attributing characteristics that people intuitively perceive to be uniquely human to nonhuman agents or events.

(...) Anthropomorphism therefore includes both physical features (...) and mental capacities that people 
believe are uniquely human, such as the capacity to have conscious awareness, possess explicit intentions, or experience secondary emotions (e.g., joy, pride, shame, guilt) (Waytz et al. 2010: 59).

On the one hand, anthropomorphism makes non-human agents worthy of moral consideration; on the other hand, agency attribution leads to them being perceived as liable for their own actions and hence deserving appropriate punishment (see Gray et al. 2007: 619). The vocabulary of modern parasitology is in fact largely shaped by our knowledge of manners and customs related to hospitality and relations with strangers in general. For instance, the organism that nourishes another is called a host, and the life environment of a parasite is described as hospitable or hostile. Moreover, parasites are often presented as conscious agents that employ various strategies and methods to enter a host body.

An important element of the image is the BIO-PARASITE's 2 ability to enter the body unnoticed, conceal his presence and delay the onset of the symptoms of illness, making the host unaware of infection until it is too late: "Outwardly, they try to act just like the host peoples. (...) Therein lies the enormous danger: these assimilated Jews remain forever foreign bodies in the organisms of their host peoples, regardless of appearances" (Hippler 1940). In Third Reich propaganda, arguably the most extreme example of applying the PEOPLE ARE PARASITES metaphor, the Jews are portrayed as a threat not only to society, but also to the physical and spiritual wellness of the Aryan race, which makes them more than simply a SOCIO-PARASITE. The metaphor of JEWISH RACE PARASITE combines the standard notion of a group living at the expense of another with the concept of BIO-PARASITE 2, i.e. a separate biological species (the Jewish race) that is morally responsible for its actions and must be eradicated for the sake of community health, as well as an element of demonic or satanic influence on the world at large (see Musolff 2016: 79f). As Musolff observes:

(4) the SOCIO-PARASITE 2 concept can be further developed into the notion of a biological threat to the host society that must be eliminated at all cost. The concepts of BIO- and SOcIO-PARASITES are blended into the construct of a superparasite 2, which combines deadly dangerousness with devilish cunning (Musolff 2016:80).

The SUPERPARASITE concept offers a new outlook on a racial group as well as a new weapon in the propaganda arsenal. On top of economic and biological destruction it introduces an element of SPIRITUAL PARASITISM, a concept widely elaborated in Third Reich propaganda (see Bärsch 2002: 49ff). At present, its use is marginal and restricted to extreme political communities, such as the users of the Stormfront forum.

It is important to note that the PARASITE metaphor used in relation to whole groups is not simply an epithet aimed at insulting someone, as is the case in interpersonal usage towards an individual; the metaphor functions as a description and statement, and can therefore be interpreted as a death threat. Regardless of which type of parasite people are categorised as, one thing remains constant: the parasite is always seen as a foreign body, an alien that sneaks in uninvited and therefore has no right to freedom or any type of resources. The metaphor implies the need to control 
the threat, either through banishment or extermination; any communication, negotiation or cooperation is out of the question.

\section{Racism in the digital age}

The PEOPLE ARE PARASITES metaphor has been used to dehumanise groups that were perceived as undesirable since the eighteenth century, and has since been widely reproduced in literature, political discourse, print media and on television. In recent years, however, it is most often employed in the context of ethnicity and race, and related issues such as immigration. The Internet, undoubtedly one of the most revolutionary inventions in the history of human communication, has provided a new kind of outlet for the reproduction of racist discourse, one where conventional mechanisms of control, such as state-imposed censorship or legal regulations, are no longer applicable. Thanks to the Internet all users are granted almost limitless access to information, as well as the possibility to reach nearly anyone on Earth. Perhaps most importantly, people with extreme views on race who in the real world would be exposed to criticism and social stigma because of their beliefs can enjoy relative anonymity and impunity for their actions. As a source of examples of usage of the PEOPLE ARE PARASITES metaphor I will use one of the most infamous Internet websites representing an undeniably racist worldview - Stormfront.org, widely considered the first major on-line platform dedicated to promoting white supremacy, nationalism and extreme rightwing ideology (see Levin 2003: 363). Stormfront's slogan proclaims that "Every month is White history month", and the website claims to be the voice to "the new, embattled White minority" (Stormfront.org). Registered members are greeted with an introductory message from Stephen Donald "Don" Black, a former Grand Wizard of the Ku Klux Klan and the owner of the website:

(5) We are a community of men and women working to ensure the survival of our people and a future for our children. We have grown steadily since first going online in 1995 . We now reach over sixty thousand unique visitors a day, but we have a long way to go. Our ultimate success will depend upon all of us, so we encourage you to participate in our forums and become active in your local community.

In fact, according to Google Analytics the site has approximately 30 thousand unique visitors a day (as of March 2017, Google Analytics 2017). The e-mail urges the users to try their best to conceal their identities and to follow the guidelines for posting, including avoidance of profanity and "racial epithets" (these are indeed censored, for instance by using abbreviations or asterisks), and the application of self-censorship: "Don't post anything you wouldn't want attributed to you in a court of law, quoted on the front page of the New York Times, or read by your mother" (Stormfront.org 2017). The website was first launched in 1991 in the form of an on-line bulletin board in support of David Duke, the former Imperial Wizard of the Ku Klux Klan, running for a post in the U.S. Senate (see Swan and Nieli 2003: 153f). It was in 1995 that Black realised its potential for reaching millions of people with a similar worldview and transformed it into the massive Internet forum it is today (ibid. 155), hosting almost 250,000 active members (as of April 2017, Stormfront.org). All 
examples in this article come from the English-speaking forum sections and are quoted with the original spelling and punctuation; emoticons, images and extra spaces were removed. The year of each of the posts is given in brackets. The examples were gathered with the help of the forum search tool provided by the website, and priority was given to the most recent posts of forum members.

\section{Metaphors and the ideology of white-supremacy}

The worldview of users of the Stormfront forum is firmly grounded in white-supremacist ideology, which is unsurprising, considering that many users identify themselves as Ku Klux Klan members, and, as mentioned before, the founder of the website himself is a former high-ranking KKK official. Consequently, much of the racial hatred expressed on the forum is directed towards AfricanAmericans, a group that is considered inferior to whites or even subhuman. Black people are often portrayed as either aggressive animals or "beasts of burden", lacking the refinement and mental capacities that characterise the more advanced white society. As targets of the PEOPLE ARE PARASITES metaphor black people are most commonly represented as SOCIO-PARASITES 2 due to their alleged inherent laziness, lack of motivation and dependence on the welfare system in host countries:

(6) The only way to get blacks out of USA or any other white country is to convince them there are better welfare payments, freebies and a pot of gold in Africa....the parasite always feeds off the fattest host (Stormfront.org 2017).

(7) What would the average Black slave have become if he had been freed? We have the answer to this: He would keep working on his original plantation for a paycheck that amounts to nothing more than the benefits he got when he was a slave, and his freedom had thus expanded to either going to work on another plantation for the same pay, or moving north and trying to mooch off the naive pity of the antislavery libtards of the time. Few took that last option because it was the unknown and required thought and effort. The opportunity to become a welfare parasite had to be brought to the southern Negro's door by libfags from the north because Blacks are so inferior that they would have remained slaves forever rather than figure out how to live off other people's tax money (Stormfront.org 2016).

In the case of African-Americans or black people in general, SOCIO-PARASITE 2 could be exchanged for a more specific WELFARE PARASITE concept. As opposed to more economically aggressive targets such as the Jews, the WELFARE PARASITE does not strive for financial dominance or actively seek ways to enrich itself at the cost of a community; instead it passively waits for government handouts, reproducing rapidly and excessively burdening the welfare system of the host country, and, in consequence, the white taxpayers. The black race is not the only target of the PEOPLE ARE WELFARE PARASITES metaphor; other non-white minorities are also commonly categorised as a burden to the state:

(8) If we lived in a pure free market society, I would still prefer to live in a white nation, but the presence of non-whites would be far less detrimental to whites. This is because of the lower IQ of Hispanics and 
blacks, which means less of them succeed, which means more money in welfare payments from whites to blacks and Hispanics. This practice of parasitism has now become a part of black and Hispanic culture, to the point where people who could succeed in the marketplace instead choose to be a parasite because of the cultural acceptance in their communities of that life strategy, as well as basic human nature which dictates that one get the greatest degree of resources for the least amount of effort (Stromfront.org 2016).

(9) Exactly these idiot beans and nigs and Ricans act like they wish whites would just disappear or go back to Europe too stupid and brainwashed to realize that the whole reason they come to America is because of what whites made it and live off our system and welfareltax dollars, our government, our inventions, our schools, our buildings, our medical and scientific achievements which they could never come close to mimicking in their craphole third world garbage dump slum failure countries. (...) Well then don't live in the lands we settled then parasite. (...) Name one thing your people have contributed to this country? Besides a sky high crime rate? (Stormfront.org 2015)

As in any other instance of usage of the PEOPLE ARE PARASITES construct, the NON-WHITES ARE WELFARE PARASITES metaphor implies an immediate call to action. In this case, the proposed solutions to the problem largely suggest a reform of the state and "cutting off" from all government benefits. Any further actions are considered optional, as the non-whites are expected to leave the country should state aid be taken away from them.

Interestingly, Asians seem to be considered relatively high up on the evolutionary ladder and "close" to the white race in terms of culture, intelligence and usefulness in a community. Several posts even suggest that a peaceful co-existence of the two races would be possible in a utopian White-Asian society. On the other hand, even though they are not typically deemed wELFARE PARASITES, there are still whole threads employing the ASIANS ARE SOCIO-PARASITES 2 metaphor. Asians are seen as a threatening race that strives for domination over the white race:

(10) They lie and they cheat and they steal constantly. They, like every other non-White race, swarm into White nations for a better life, bringing their corruption with them and destroying what we have, all while telling us how oppressive and hateful and vile we are (Stormfront.org 2016).

(11) How can a superior race be dominated by a lesser race then? I mean white race be dominated by Asians and controlled by the jews (Stromfront.org 2017)

(12) How can a man be dominated by the combination of a mosquito and a malaria parasite? Stop thinking in terms of superior and inferior and start thinking in terms of hosts and parasites. We need to cleanse the hosts and keep the parasites from doing what parasites do. We need to make the hosts healthy and parasite free. We need complete and total racial separation. Stop the hate, separate (Stormfront.org 2017). 
In the case of Asians integrated in Western societies it is hard to pinpoint the actual mappings between the source and target domains of the ASIANS ARE PARASITES metaphor. One possible explanation supported by example (12) is that the sole issue that fuels this conceptualisation of Asians is in fact race, meaning the categorisation of a group in terms of a separate biological species. This would suggest a blend with the concept of BIO-PARASITE, with the focus predominantly on biological aspects of the source domain.

\section{Immigrants and biological infection}

Immigration has always been a heated political topic, especially in the context of non-white refugees with a different cultural and religious background coming to Western countries. In recent years, particularly since the $9 / 11$ attacks, this difficult debate has been fuelled by fear of an impending terrorist threat coming from the Muslim world. Europe has also experienced a shift in the perception of immigrants and refugees, with multiple European citizens with an immigrant background involved in terrorist activities raising important questions about the viability and effectiveness of immigrant integration programmes. Both in Europe and the US this general fear of immigration has contributed to an overwhelming rise in support for populist right-wing political parties and politicians, and many have now established themselves in a position of power. Unsurprisingly, the Stormfront community represents a radical political stance in this debate.

The main issue raised by the IMMIGRANTS ARE PARASITES metaphor remains that of money, that is financial support for refugees and migrants provided by the state. In the overwhelming majority of cases the concept of SOCIO-PARASITE 2 is employed to underline the economic aspects of migration:

(13) It's the smell of money that will be the migrants demise, these people aren't looking for refugee, they are searching for the best welfare system to exploit and parasite on (Stormfront.org 2015).

(14) [Re:SuperiorhomeforSyrian refugees].Letmegetthisstraight, thegovernmentboughtafivestarmansion for a jobless parasite welfare suckling family? No wonder they call it broken britain! (Stormfront.org 2017)

(15) Unfortunately it's not your average person that wanted the government to plow our hard earned taxes into these oxygen thieves (Stormfront.org 2017).

(16) Muslims are a destructive parasite to any host they latch onto. They are a non assimilating populace feeding off the sympathy of half wits. Wait until they become the majority within a particular living space, and you'll see how peaceful these refugees are (Stormfront.org 2017).

In addition to being destructive to the economy and draining the HOST COUNTRY's resources, immigrants are also accused of carrying actual parasites (BIO-PARASITE 1/2) and infecting the HOST POPULATION in a scenario that Musolff calls a "double PARASITE whammy" (Musolff 2016: 78): 
(17) It's the homeless ex-servicemen epidemic that is truly disgusting as they are the ones that should be getting housing, not some flea ridden parasite from some sandpit south of the equator (Stormfront.org 2017).

(18) [Re: The floating slum on stilts: Staggering pictures of the families who fight for survival on a sea of festering filth] Breeding ground for super viruses (Stormfront.org 2017).

In the thread entitled 8 ways illegal immigrants are making you sick the author enumerates several diseases carried by immigrants, including cysticercosis, a parasitic disease caused by the pork tapeworm, and adds:

(19) You can call me a racist all you want, but if turning a blind eye to (or heaven forbid, welcoming with open arms) these illegals means opening up my children's children to these awful diseases, you can forget it. I won't stand for what these moochers are doing to our land, our school-rooms or our hospitals-and neither should you (Stormfront.org 2008).

It is interesting to note that these examples from an extremist white-nationalist Internet forum are in fact not that different from those found in mainstream media (compare Musolff 2016: 80-87). The worldview expressed through the IMMIGRANTS ARE PARASITES metaphor has now moved from the periphery to the very centre of public discourse, which raises the following question: can the radical attitudes presented on a forum such as Stormfront.org any longer be described as truly "marginal" or "extremist"?

\section{The ultimate global SUPERPARASITE}

The Jews, both the ones that live within American or European societies and the ones in Israel, are undeniably the most loathed, feared and hated racial group represented on the forum, with almost every thread containing some form of attribution of blame for any event that is seen as detrimental to the well-being of society or the white race in general. It is important to note that Jews are considered a separate race, essentially non-white but able to blend into white society because of physical similarities (the blonde and fair-skinned Barbara Streisand is often named as one example of such an impostor). That clear categorisation of Jews as a biologically defined race in a literal sense is identical to the view of "the Jewish race" promoted in Third Reich propaganda. Another link between the worldview of the Nazi Party and that of Stormfront users is a portrayal of the Jewish race that falls in line with not just one, but multiple variants of the PEOPLE ARE PARASITES metaphor. First, the Jews are portrayed as the socio-PARASITE 2, i.e. a collective of individuals who do not produce any goods or make any other form of contribution to society, while simultaneously extorting more than their fair share of resources. Consider these examples:

(20) Jews piggybacked the settlement of Europeans in North America \& applied their well rehearsed number one party trick, c'est-à-dire mafioso tactics/money lending \& banking malpractices in a new 
nation populated by desperate Europeans who were too busy enriching themselves to even care about the parasite which was prospering in their new land (Stormfront.org, 2017).

(21) The darker the city, the more of the nightclubs seem to crop up. No doubt Jews own a lot of them, they are a parasite on the local community which is just the sort of "business" Jews like (Stormfront.org, 2017).

(22) Jews think all non-jews,approximately $98 \%$ of mankind are cattle to serve the jews and all fruits/ money/possesions of the people belong to the jews. Very vile and dangerous people. A jew is never a victim but always the perpetrator !!! (Stormfront.org, 2017).

(23) The real enemy is the parasite within that has latched hold of all the levers of power and influence in the West (Stormfront.org 2017).

The destructive force of the SOcIO-PARAsite 2 lies within its ability to take money and goods from honest, hard-working white people. The Jews employ immoral, illegal or at least dishonest tactics to make profit off an unsuspecting, innocent and naive community. In contrast to Black or Hispanic racial groups, they do not limit themselves to living off government handouts in the form of welfare cheques; their strategy is to establish themselves in a position of power that grants them unlimited access to money and other assets.

Secondly, the portrayal of Jews on the Stormfront forum meets all the conditions of the віO-PARASITE 2 scenario, that is: (1) the target is categorised as a separate species whose survival strategy involves actual biological parasitism; (2) the target cannot thrive on its own; the non-mutual relationship with the host is a necessary condition for survival; (3) the target either weakens the host by extracting vital nutrients, causes a biological illness with its presence, or infects the body with a deadly disease. As mentioned before, the Jews are considered a separate race that is hostile to whites. In addition, they are often portrayed as a different biological species altogether, drawing from the source domain of well-known parasitic animals:

(24) [Original post] Scientists have discovered a parasitic insect with a reproductive strategy straight out of an Alien movie. Dubbed the "crypt-keeper wasp," it infects a rival species with its young, which, after hatching, proceed to chew their way out through the victim's head.

[Reply] Also known as the Jew Wasp.

(Thread title: "Diabolical Parasite Grows Inside Baby Wasps and Eats Their Brains to Escape", Stormfront. org 2017)

(25) Every jew is a "holocaust survivor" because there was no Holocaust! I wonder when the Germans will finally grow some balls and say enough is enough and don't let those jewish ticks fleece them anymore. Every dog knows a tick is a dangerous parasite and not a friend. Todays germans unfortunately don't... (Stormfront.org 2017). 
The cuckoo is the perfect example of a source domain that is broadly known and embedded in folk mythology and group mentality. This brood parasite is known for laying its eggs in other birds' nests so that the young are cared for and fed by the host. The premise led to the formation of the lexical blend "cuckservative", a term used to describe conservative politicians that allow the parasite species to thrive in the HOST NEST:

(26) Zionists know that cuckservatives are their best friends, whereas the left features a lot of "anti-Semites" that dare to criticise Israel (see the UN, what a bunch of anti-Semites, and Obongo) (Stormfront.org 2017).

An important element of the parasite source domain is the ability of certain biological species to control the behaviour of the host by means of changing brain chemistry, causing a hormonal imbalance, or affecting the physical structure of the brain:

(27) Everyone should read the life cycle of Toxoplasma gondii. It's a brain eating parasite that infects mice, takes over the brain of the mouse so that they become unafraid of cats, then the cat eats the mouse and the parasite is able to reproduce in the cat, which then spreads the cysts to the environment where they are picked up again by more mice, starting the cycle all over again. The power of this parasite to take over and control the brains of mice for its own purposes, causing the mice to commit suicide in the process, is truly horrifying. That this parasite is able to do the same thing and take over and control the brains of humans is even more horrifying. And it has occured to me that the Jews have done something similar to the white race, by waging psychological warfare, and convincing whites to serve the Jews and to commit racial suicide in the process (Stormfront.org 2017).

(28) "The jews are able to prevent us from listening to ourselves." and that is what certain parasites in nature do, they take over the central nervous system and drive the host to kill itself. [external link: Suicide Grasshoppers Brainwashed by Parasite Worms].

(...) Whites are only committing suicide because they can literally no longer think. Their thinking has been hijacked by the Jewish parasite, which seeks to destroy it (Stormfront.org, 2017).

(29) The jews are a kind of parasite. They are like slaver ants taking over a host ant colony. They get the workers to kill the host ant queen, then use up the host ant colony to make more slaver ants. When they have used up the host ants of one colony, they move on to another (Stormfront.org 2016).

This ability of the PARASITE to control the mind of the HOST and in effect turn him into a slave, drive him to self-destructive behaviour and ultimately suicide, or make him turn against his own species is what makes the JEWS ARE BIO-PARASITES 2 metaphor so powerful and easy to decode. The enemy is not a stronger animal that can be seen, hunted, controlled and defeated; the strength of the metaphor lies in a universal fear of the unseen threat that slowly takes over our body and mind. 
Another example of mapping between the source and target domain in the JEWS ARE BIO-PARASITES 2 metaphor is the fact that they are allegedly unable to survive on their own without a host body to feed off:

(30) Even the Jews couldn't live in other non-White civilizations, and had to parasite off Whites to survive, just like all the other non-Whites who they kid themselves they are superior to. If anything, this fact validates Whites intellectual superiority over all other races, including the Jew (Stormfront.org 2017).

The third and perhaps most fear-inducing aspect of the JEWS ARE BIO-PARASITES 2 metaphor is the illness that they infect the HOST вODY with. In the worldview presented on the Stormfront forum the disease induced by the JEWISH PARASITE is in fact immigration from non-white countries. The immigrants are seen as rapidly multiplying microbes, or, alternatively, another breed of parasite that feeds off the HOST BODY. This creates a DOUBLE PARASITE INFECTION scenario: the initial BIO-PARASITE 2 infects the BODY and takes over the central nervous system making the HOST defenceless, while simultaneously introducing a whole army of SOCIO-PARASITES 2 that drain the HOST's resources:

(31) The Jews are just parasite degenerate zionists on average. I expect them to push for the importation of blacks and arabs to our homelands, they are at war with us and our innocent young. That is to be expected, as are the muds attacking our women and children. I can't blame them, that is what they do. They are animals of the lowest kind. There is no excuse for white cuck traitors though, i have no mercy for them. Crush them all out of existence. Not only as justice for the victims of this brown invasion, its a matter of racial hygiene. We cannot allow these traitors to thrive in our midst, they are cancer. If we clean up Europe (and we will) in 50 years the offspring of these mentally diseased cucks will be importing more savages to hurt our people (Stormfront.org 2017)

(32) Its funny how the (((politicians))) can't figure out the reality of why the natives (white europeans) are not having big families... let alone one child.. its because we are being financially restrained as well as cucked by paying for non-whites to eat, live, and reproduce off of us.. if politicians want to increase the native birthrates... they are going to have the biggest parasite out of their country that is creating this... and that is the jews/zionists that are in control or influencing that country... (Stormfront.org 2017)

In the case of the Jews, the symptoms of a parasite infection are sometimes similar to demonic possession. Another added dimension of the JEWS ARE PARASITES metaphor is the element of "spiritual" sickness that they inflict:

(33) For example in my opinion as to why white western men are spiritually sick is because the one racial group that owns the majority of the media, entertainment, music, and everything else interjects poisonous ideologiesandsocialnormsontooursocietiesandontop of that... when weresistthispoison...weareconsidered "intolerant", "racist", or whatever anti-white statement/slur they will throw at us... (Stormfront.org 2017) 
The SPIRITUAL PARASITE concept has already been explored by the Nazi Party, which likened the Jews to a satanic cult following the destructive religion of Judaism. In fact, both in German propaganda and on the Stormfront forum the Jews are often represented as the spawn of Satan, introducing an additional antithesis of "godly whites" versus "devil-worshipping Jews", often supported by biblical examples:

(34) A "good jew" would have been Jesus. But the Jews killed him because he wanted to save them from their sickness called Judaism. A good jew would be a jew that is not a jew anymore. Like a Viper with it's poisonous fangs removed! Jews are very dangerous because they are the children of Satan (Stormfront.org 2017).

(35) Jesus was no jew! Jesus wanted to save the Jews though from their sickness called Judaism but the Childen of Satan killed him like they killed Hitler who wanted to free the Germans from the jewish parasites. Only a dead parasite is a good parasite! (Stormfront.org 2017).

(36) Parasite jews burrow into a Christian country and do all kinds of damage from the inside (Stormfront.org 2017).

Just as in Third Reich propaganda, a seemingly incompatible blend of the socio- and BIO-PARASITE concepts with the element of demonic or diabolical forces gives way to the all-encompassing SUPERPARASITE.

\section{Conclusions}

The examples from the Stormfront forum discussed above all tend to follow the same pattern of usage and play a part in the narrative-argumentative scrounge scenario (see Musolff 2016: 83-84), one where the outgroup scrounges from the ingroup. The PEOPLE ARE PARASITES metaphor employs terminology that presents the target as a disgusting and dangerous biological organism and castigates non-white racial groups (including Jews) as detrimental to the HOST BODY. In contrast to the relatively simple scenarios employed by mainstream media, where the usage of the PEOPLE ARE PARASITES metaphor tends to be viewed as highly controversial, the worldview presented on the Stormfront forum is far more complex and can be summarised as the following scenario: 'INTERNATIONAL JEWRY' IS A GLOBAL SUPERPARASITE: as SOCIO-PARASITES 2 they feed off the resources of the HOST COMMUNITY and avoid any form of contribution; as BIO-PARASITES 2 they represent a separate species that attempts to conceal its presence by MIMICKING THE HOST while slowly poisoning the HOSт воDY, intentionally preventing natural processes of healing, and driving the HOST to self-destruction by means of mind control. The nation of Israel is the WORLD PARASITE that follows that same strategy on a global scale: it takes the resources of the HOST COMMUNITY (all the world's nations), infects the WORLD BODY with a CHRONIC ILLNESS, and blocks its natural defence mechanisms. After gaining both economic and psychological control of the HOST, the PARASITE drives the HOST to extinction by weakening the BODY's immunity against the SOCIO-PARASITE/WELFARE 
PARASITE that was already present in the community (African-Americans, Asians, Indians, etc.) and introducing a new INFECTION of rapidly multiplying SOCIO-PARASITES (non-white immigrants) that further drain the host's resources. These new socIO-PARASITES are in turn infected by actual parasites (BIO-PARASITE $1 / 2$ ) that contaminate the HOST POPULATION. The INFECTION that spreads to all parts of the BODY is not only biological, economic and psychological in nature; the presence of the SUPERPARASITE also affects the spiritual domain by undermining true faith and values. This apocalyptic representation of political reality is no coincidence. As Musolff argues:

(37) Scenarios in themselves are not metaphor-specific or grounded in a particular source domain, but should rather be seen as conceptual patterns that emerge in discourse and are made narratively and argumentatively coherent by specific metaphors, which in turn makes them prime candidates for 'selffulfilling prophecies' (Musolff 2016: 87),

and it is therefore fair to assume that the structuring of a metaphorical scenario is in fact a conscious and deliberate act where both the speakers and the recipients are fully aware of its implications and the ideology they subscribe to (see Musolff 2016: 88). This elevates the status of the metaphor from a vehicle of unconscious bias to socially meaningful action, where the authors can and indeed should be held accountable for its implications. The PEOPLE ARE PARASITES metaphor is especially persuasive, as it entails an immediate call to action whose effects can potentially be no longer metaphorical. If the cognitive impact on the recipients is, just as in the case of Third Reich propaganda, full social acceptance of a biased worldview, the real-world consequences can in fact be catastrophic.

The constantly evolving PEOPLE ARE PARASITES metaphor definitely merits further consideration, especially at the present time, with right-wing ideology rapidly gaining support on both sides of the Atlantic. Extreme views held by marginal communities such as Stormfront are now making their way into public and political discourse, and, as demonstrated in this article, Conceptual Metaphor Theory can be a useful tool in the identification and analysis of such phenomena. While a prescriptive approach aimed at counteracting such discourses is beyond the scope of this paper, cognitive metaphor analysis can be successfully employed by international projects such as C.O.N.T.A.C.T. (reportinghate.eu) to raise awareness about hate speech and construct a legal framework supporting victims of violence.

\section{References}

Bärsch, Claus-Ekkehard. 2002. Die politische Religion des Nationalsozialismus. Munich: Fink.

Fitzpatrick, Sheila. 2006. Social parasites: How tramps, idle youth, and busy entrepreneurs impeded the soviet march to communism. Cahiers $d u$ Monde russe 47(1/2), 377-408.

Gray, Heather M., Gray Kurt and Daniel M. Wegner. 2007. Dimensions of mind perception. Science 315, 619. 
Hodson, Gordon, Kteily Nour and Mark Hoffarth. 2014. Of filthy pigs and subhuman mongrels: dehumanization, disgust, and intergroup prejudice. TPM - Testing, Psychometrics, Methodology in Applied Psychology 21(3), 267-284.

Lakoff, George and Mark Johnson. 1980. Metaphors We Live By. Chicago: University of Chicago Press.

Lakoff, George. 1993. The contemporary theory of metaphor. In: Ortony, Andrew (ed.), Metaphor and Thought, 202-251. Cambridge: Cambridge University Press.

Levin, Brian. 2003. Cyberhate. In: Perry, Barbara (ed.), Hate and Bias Crime: A Reader, 363-382. New York/London: Routledge.

Musolff, Andreas. 2007. What role do metaphors play in racial prejudice? The function of antisemitic imagery in Hitler's "Mein Kampf”. Patterns of Prejudice 41(1), 21-44.

Musolff, Andreas. 2016. Political Metaphor Analysis. Discourse and Scenarios. London: Bloomsbury Academic.

Schaller, Mark and Justin H. Park. 2011. The behavioral immune system (and why it matters). Current Directions in Psychological Science 20, 99-103.

Smith, David Livingstone. 2011. Less Than Human: Why We Demean, Enslave, and Exterminate Others. New York: St. Martin's Press.

Swain, Carol M. and Russ Nieli. 2003. Contemporary Voices of White Nationalism in America. Cambridge: Cambridge University Press.

Thibodeau, Paul H., McClelland James L. and Lera Boroditsky. 2009. When a bad metaphor may not be a victimless crime: The role of metaphor in social policy. In: Taatgen, Niels and Hedderik van Rijn (eds.), Proceedings of the 31st Annual Conference of the Cognitive Science Society, 809814. Austin, TX: Cognitive Science Society.

Waytz, Adam, Epley Nicholas and John T. Carcioppo. 2010. Social cognition unbound: Insights into anthropomorphism and dehumanization. Current Directions in Psychological Science 19(1), $58-62$.

\section{Internet sources}

Google Analytics

https://www.seethestats.com/site/stormfront.org (10 April 2017)

Hippler, Fritz. 1940. Der Ewige Jude.

https://archive.org/details/1940-Der-Ewige-Jude (10 April 2017).

Online Etymology Dictionary http://www.etymonline.com/index.php?term=parasite\&allowed_in frame $=0$ (15 April 2017)

Stormfront.org (10 April 2017) 